\title{
Implementation of Provisions on the Rights of Women Nurses Working in Hospitals Based on Human Rights Review
}

\author{
(Implementasi Ketentuan Hak - Hak Perawat Perempuan Yang Bekerja di Rumah Sakit \\ Berdasarkan Tinjauan Hak Asasi Manusia)
}

\author{
Aprilia Ninda Giasma; Edward Kurnia; dan Yovita Indrayati \\ email: Anindagiasma12@gmail.com
}

Master of Health Law, Soegijapranata Catholic University Semarang

\begin{abstract}
One of the health workers is nurses who have the rights as workers and as nurses. The rights that must be fulfilled as nurses and workers are prohibition against labour, protection of female workers at night, menstruation leave, maternity and maternity leave, miscarriage leave and breastfeeding rights, but the implementation has not been carried out optimally.

This research is a sociological juridical study with qualitative descriptive research specifications. The study was conducted at the emergency department and hospital inpatient installations. The method of data collection is done by observation and interviews and literature studies to obtain the data needed.

The results of the research in the two hospitals showed that the rights of female nurses as workers were contained in company regulations and employment agreements, whereas as a profession there were nurses by-laws and clinical privileges. The regulation of women's nurses' rights is contained in the Labor, Health and Nursing laws. In the implementation of these rights, namely the right of maternity leave and childbirth, the provision of wages during leave and protection of female nurses who work at night and work facilities according to standards have not been carried out optimally. The work agreement does not fulfil one of the legal requirements of the agreement, namely the halal cause and for the company regulation applies the superior lex principle derogate lege inferiori. Factors that influence the implementation of provisions in the form of inhibiting and supporting factors.
\end{abstract}

Keywords: Implementation, Nurse Rights, Women, Human Rights

\begin{abstract}
Abstrak: Tenaga kesehatan salah satunya yaitu perawat memiliki hak sebagai pekerja dan sebagai perawat. Hak yang harus dipenuhi sebagai perawat dan pekerja yaitu larangan phk, perlindungan pekerja perempuan pada malam hari, cuti haid, cuti hamil dan melahirkan, cuti keguguran dan hak menyusui, namun dalam pelaksanaannya belum terlaksana secara optimal.

Penelitian ini merupakan penelitian yuridis sosiologis dengan spesifikasi penelitian deskriptif kualitatif. Penelitian dilakukan di instalasi gawat darurat dan instalasi rawat inap rumah sakit. Metode pengumpulan data dilakukan dengan observasi dan wawancara serta studi kepustakaan untuk memperoleh data yang dibutuhkan.

Hasil penelitian di kedua rumah sakit didapatkan hasil bahwa hak - hak perawat perempuan sebagai pekerja terdapat di dalam peraturan perusahaan dan perjanjian kerja, sedangkan sebagai profesi terdapat di nurse by laws dan clinical privilage. Pengaturan hak perawat perempuan terdapat pada undang - undang tentang Ketenagakerjaan, Tenaga Kesehatan serta Keperawatan. Dalam implementasi hak - hak tersebut yaitu hak cuti hamil dan melahirkan, pemberian upah selama cuti dan perlindungan terhadap perawat perempuan yang bekerja pada malam hari serta fasilitas kerja sesuai standar belum terlaksana secara optimal. Pada perjanjian kerja tidak memenuhi salah satu syarat sahnya perjanjian yaitu kausa yang halal serta untuk peraturan perusahaan berlaku asas lex superior derogat lege inferiori. Faktor - faktor yang mempengaruhi implementasi ketentuan berupa faktor penghambat dan pendukung.
\end{abstract}

Kata kunci: Hak Perawat, Perempuan, Hak Asasi Manusia 


\section{PENDAHULUAN}

Perawat dalam memberikan pelayanan kesehatan kepada masyarakat yaitu memiliki hak sebagai pekerja dan sebagai profesi perawat. Pengaturan hak perawat perempuan sebagai pekerja terdapat pada Undang - Undang No.13 Tahun 2003 tentang Ketenagakerjaan, sedangkan pengaturan perawat sebagai profesi terdapat pada Undang - Undang No.36 Tahun 2014 tentang Tenaga Kesehatan serta Undang - Undang No.38 Tahun 2014 tentang Keperawatan.

Hak reproduksi yang diberikan pada pekerja perempuan ini telah diatur dalam Undang Undang No.13 Tahun 2003 tentang Ketenagakerjaan serta konvensi International Labour Organization (ILO) diantaranya Pasal 76 ayat (3) tentang perlindungan terhadap pekerja perempuan yang bekerja pada malam hari, Pasal 81 ayat (1) tentang hak cuti menstruasi, Pasal 82 ayat (1) tentang hak cuti hamil dan melahirkan, Pasal 82 ayat (2) tentang hak cuti keguguran, Pasal 83 tentang hak menyusui, dan Pasal 76 ayat (2) Undang - Undang No.13 Tahun 2003 tentang Ketenagakerjaan.

Dalam pelaksaan hak - hak tersebut belum sepenuhnya terpenuhi. Hal tersebut didukung dengan penelitian sebelumnya oleh Ana Atika Helmi Vida, dkk didapatkan hasil adanya hak yang terlanggar bagi tenaga kerja perempuan yang bekerja pada malam hari. ${ }^{1}$ Penelitian lainnya yang dilakukan oleh Ivana Dian Kristanti didapatkan hasil perlindungan yang diberikan terhadap perawat yang bekerja pada malam hari belum maksimal, hal ini disebabkan adanya beberapa kendala yang menghambat pelaksanaan perlindungan hukum tersebut yaitu kendala dari rumah sakit, pihak perawat, Dinas Tenaga Kerja, Transmigrasi dan Sosial Kota Magelang. ${ }^{2}$

Dengan belum terlaksananya hak - hak perawat perempuan sebagai pekerja perempuan seperti yang disebutkan di atas, maka penelitian ini difokuskan pada analisis penelitian hukum terhadap implementasi ketentuan hak-hak perawat perempuan yang bekerja di rumah sakit. Berdasarkan latar belakang di atas, maka penelitian akan membahas tentang "Implementasi Ketentuan Hak - Hak Perawat Perempuan yang Bekerja Di Rumah Sakit Berdasarkan Tinjauan Hak Asasi Manusia."

\section{PERUMUSAN MASALAH}

Berdasarkan latar belakang masalah maka dirumuskan terdapat 3 perumusan masalah yaitu peraturan internal rumah sakit, implementasi ketentuan hak - hak perawat perempuan yang bekerja di rumah sakit dan faktor - faktor yang mempengaruhi implementasi ketentuan hak - hak perawat yang bekerja di rumah sakit.

Tenaga kesehatan yang bekerja di rumah sakit membentuk hubungan hukum yaitu berupa hubungan kerja antara pekerja dan rumah sakit. Hubungan kerja dapat terjadi jika antara buruh dan majikan telah mengadakan perjanjian, dimana buruh menyanggupi untuk bekerja, sedangkan majikan bersedia membayar upah/gaji kepada buruh tersebut. Hubungan kerja diatur dalam Undang-Undang No.13 Tahun 2003 tentang Ketenagakerjaan pada Bab IX Pasal 50 sampai dengan Pasal 66.

\footnotetext{
1 Vida, Ana Atika Helmi, dkk : “Perlindungan Atas Terlanggarnya Hak Secara Potensial Bagi Tenaga Kerja Perempuan Yang Bekerja Di Malam Hari Berdasarkan Undang-Undang No.13 Tahun 2003 Tentang Ketenagakerjaan", 2013,Universitas Jember, Artikel IImiah Hasil Penelitian Mahasiswa 2013, hlm.10

2 Kristanti, Ivana Dian:"Perlindungan Hukum Terhadap Perawat Yang Bekerja Pada Malam Hari Di Rumah Sakit Harapan", Kota Magelang, 2014, Universitas Atma Jaya Yogyakarta, Jurnal Ilmu Hukum, hlm. 13-15
} 
"Pengertian yang pertama disebutkan dalam ketentuan Pasal 1601a Kitab Undang - Undang Hukum Perdata, mengenai Perjanjian Kerja disebutkan: Perjanjian Kerja adalah suatu perjanjian di mana pihak yang satu si buruh, mengikatkan dirinya untuk di bawah perintahnya pihak yang lain, si majikan untuk suatu waktu tertentu, melakukan pekerjaan dengan menerima upah." 3 "Pengertian lain dari perjanjian kerja ialah suatu perjanjian yang diadakan oleh majikan/perusahaan di satu pihak dengan buruh/pegawai di lain pihak, dimana ditentukan bahwa buruh/ pegawai mengikatkan diri untuk bekerja pada majikan/ perusahaan, dan majikan/perusahaan yang bersangkutan mengikatkan diri pula untuk memberikan imbalan kerja (berupa gaji, upah, berbagai fasilitas, dan sebagainya) dalam jumlah tertentu serta pada waktu - waktu tertentu pula."4

Syarat sahnya suatu perjanjian atau persetujuan telah ditentukan dalam Pasal 1320 Kitab Undang - Undang Hukum Perdata yaitu kesepakatan antara kedua belah pihak, kecakapan, objek tertentu dan suatu hal yang halal. Perjanjian kerja umumnya hanya memuat syarat kerja yang sederhana yaitu mengenai upah, jam kerja dan pembagian lain - lain.

Oleh karena itu, diperlukan peraturan yang lebih lengkap mengatur tentang syarat - syarat kerja yang disebut dengan peraturan perusahaan. Pengertian peraturan perusahaan pada Pasal 1 butir 20 Undang - Undang No.13 Tahun 2003 tentang Ketenagakerjaan yaitu "Peraturan Perusahaan adalah peraturan yang dibuat secara tertulis oleh pengusaha yang memuat syarat-syarat kerja dan tata tertib perusahaan."

Dengan adanya perjanjian kerja maka menimbulkan hak dan kewajiban dari masing masing pihak. "Antara hak dan kewajiban terdapat hubungan yang sangat erat. Hak itu memberi kenikmatan dan keleluasaan kepada individu dalam melaksanakannya, sedangkan kewajiban merupakan pembatasan dan beban, sehingga yang menonjol ialah segi aktif dalam hubungan hukum itu, yaitu hak." 5

Manusia dan hak asasi manusia tidak dapat dipisahkan karena sejak manusia lahir di dunia telah membawa hak - hak kodrat. Dengan adanya hak asasi manusia maka hak - hak individual tersebut harus dihormati dan dihargai sebagai hak yang mendapat perlindungan oleh negara dan pemerintah. Di Indonesia hak reproduksi perempuan diatur pada Undang Undang No.13 Tahun 2003 tentang Ketenagakerjaan.

Hak - hak perawat pekerja perempuan dalam hak kesehatan reproduksi sebagai pekerja dan profesi yaitu hak larangan pemutusan hubungan kerja terhadap pekerja perempuan hamil, melahirkan, gugur kandungan, atau menyusui bayinya, perlindungan terhadap pekerja perempuan yang bekerja pada malam hari, masa menyusui, cuti haid, cuti hamil dan melahirkan serta cuti keguguran. Hak perawat sebagai profesi diatur pada Undang Undang No.36 Tahun 2014 tentang Tenaga Kesehatan serta Undang - Undang No.38 Tahun 2014 tentang Keperawatan.

\footnotetext{
3 Djumadi, 2008, Hukum Perburuhan Perjanjian Kerja, Ed.2, Jakarta: PT RajaGrafindo Persada, hlm.29

4 Halim, Ridwan A, 1990, Hukum Perburuhan Dalam Tanya Jawab, Cet.2, Jakarta: Ghalia Indonesia, hlm.22

5 Mertokusumo, Sudikno, 1986, Mengenal Hukum (Suatu Pengantar), Cet.1, Yogyakarta: Liberty Yogyakarta, hlm.39
} 


\section{METODE PENELITIAN}

Penelitian ini menggunakan metode pendekatan yuridis sosiologis dengan spesifikasi penelitian deskriptif kualitatif. Penelitian dilakukan di Rumah Sakit Permata Bunda Purwodadi dan Rumah Sakit Roemani Muhammadiyah Semarang. Penelitian ini menggunakan data primer dan data sekunder.

Metode pengumpulan data dilakukan dengan observasi dan wawancara serta studi kepustakaan untuk memperoleh data yang dibutuhkan. Wawancara dilakukan pada informan yaitu pihak Persatuan Perawat Nasional Indonesia, personalia rumah sakit, kepala ruang instalasi gawat darurat dan instalasi ruang inap.

Responden yaitu 4 perawat instalasi gawat darurat dan 8 perawat instalasi rawat inap Rumah Sakit Permata Bunda Purwodadi serta 4 perawat instalasi gawat darurat dan 8 perawat instalasi rawat inap Rumah Sakit Roemani Muhammadiyah Semarang. Analisis yang digunakan dalam penelitian ini adalah analisis kualitatif dengan menggunakan teori hukum, asas hukum, dan peraturan perundang - undangan yang terkait dengan penelitian.

\section{PEMBAHASAN}

Bentuk peraturan internal rumah sakit antara lain peraturan perusahaan, hospital by laws, perjanjian kerja, dan medical by laws. Di hospital by laws dan medical by laws tidak mengatur tentang hak perawat. Di Rumah Sakit Permata Bunda Purwodadi dan Rumah Sakit Roemani Muhammadiyah Semarang peraturan internal rumah sakit yang mengatur tentang hak hak perawat sebagai pekerja terdapat dalam peraturan perusahaan dan perjanjian kerja.

Hak perawat sebagai profesi di Rumah Sakit Permata Bunda Purwodadi diatur dalam nurse by laws dan di Rumah Sakit Roemani Muhammadiyah Semarang hak tersebut diatur dalam kewenangan klinis. Dari hasil penelitian nurse by laws masih dalam tahap rancangan/draff. Untuk kewenangan klinis mengatur tentang sejauh mana kewenangan/kompetensi perawat dapat melakukan tindakan medis kepada pasien.

Pasal - pasal yang telah disebutkan dalam perjanjian kerja tersebut telah sesuai dengan teori tentang perjanjian kerja yang dikemukakan oleh Ridwan A Halim. Isi dalam perjanjian tersebut sesuai dengan Pasal 54 Undang - Undang No.13 Tahun 2003 tentang Ketenagakerjaan. Pada perjanjian kerja Rumah Sakit Permata Bunda Purwodadi dan Rumah Sakit Roemani Muhammadiyah Semarang tidak memenuhi salah satu syarat sahnya perjanjian yang terdapat pada Pasal 1320 Kitab Undang-Undang Hukum Perdata dan Pasal 52 Undang-Undang No.13 Tahun 2003 tentang Ketenagakerjaan yaitu kausa yang halal yaitu pemberian upah karena perjanjian tersebut bertentangan dengan Peraturan Pemerintah Republik Indonesia Nomor 78 Tahun 2015 tentang Pengupahan dan Keputusan Gubernur Jawa Tengah Nomor 560/94 Tahun 2017 tentang Upah Minimum Pada 35 (Tiga Puluh Lima) Kabupaten/Kota Di Provinsi Jawa Tengah Tahun 2018. Oleh karena itu, perjanjian tersebut batal demi hukum karena tidak memenuhi syarat objektif perjanjian.

Peraturan perusahaan di Rumah Sakit Permata Bunda Purwodadi dan Rumah Sakit Roemani Muhammadiyah Semarang hanya berlaku sampai dengan 2 tahun, hal tersebut sesuai dengan Pasal 111 Undang - Undang No.13 Tahun 2003 tentang Ketenagakerjaan. Pembuatan peraturan perusahaan rumah sakit mengacu pada Undang-Undang No.13 Tahun 2003 tentang Ketenagakerjaan. 
Peraturan perusahaan Rumah Sakit Permata Bunda Purwodadi dan Rumah Sakit Roemani Muhammadiyah Semarang berlaku asas lex superior derogat legi inferiori yang artinya jika terjadi pertentangan antara undang - undang yang lebih tinggi dengan yang lebih rendah, maka diberlakukan adalah ketentuan yang lebih tinggi. Hal tersebut berkaitan dengan hak cuti hamil dan melahirkan, pemberian upah selama masa cuti, dan perlindungan perawat perempuan yang bekerja pada malam hari.

Peraturan internal yaitu perjanjian kerja dan peraturan perusahaan tidak sesuai dengan teori hukum hierarki karena bertentangan dengan undang - undang sehingga peraturan internal tersebut belum dapat menjamin perlindungan bagi perawat. Dengan belum terlaksananya hak - hak tersebut maka bertentangan dengan teori hak menurut Paton. Rumah sakit yang peraturan internal bertentangan dengan undang - undang maka dapat dikenal sanksi sesuai dengan Pasal 185 Undang - Undang No.13 Tahun 2003 tentang Ketenagakerjaan.

Hak perawat perempuan dalam Deklarasi Universal Hak Asasi Manusia sebagai pekerja termasuk dalam kategori economic, social and cultural rights karena termasuk dalam hak positif yang tidak dapat dituntut di muka pengadilan. Hak perawat sebagai profesi termasuk dalam kategori civil of political rights karena termasuk hak negatif sehingga dapat dituntut di muka pengadilan.

Hak perawat perempuan sebagai pekerja tanpa diskriminasi terdapat pada Pasal 23 Deklarasi Universal Hak Asasi Manusia (DUHAM) dan hak perawat sebagai profesi terdapat pada Pasal 7 Deklarasi Universal Hak Asasi Manusia. Hasil penelitian dilapangan didapatkan hasil bahwa implementasi ketentuan hak - hak perawat perempuan sebagai pekerja perempuan di rumah sakit tersebut belum terlaksana menurut Undang - Undang No.13 Tahun 2003 tentang Ketenagakerjaan dan Pasal 2 Keputusan Menteri Tenaga Kerja dan Transmigrasi No. KEP 224/MEN/2003 tentang Kewajiban Pengusaha yang Mempekerjakan Pekerja/Buruh Perempuan antara pukul 23.00 sampai dengan 07.00 yaitu hak cuti hamil dan melahirkan, pemberian upah selama cuti dan perlindungan terhadap perawat perempuan yang bekerja pada malam hari.

Implementasi ketentuan hak - hak perawat perempuan tersebut juga belum sesuai menurut Pasal 36 Undang-Undang No.38 Tahun 2014 tentang Keperawatan dan Pasal 57 Undang - Undang No.36 Tahun 2014 tentang Tenaga Kesehatan yaitu terkait memperoleh hak lain yang sesuai dengan ketentuan peraturan perundang - undangan dan fasilitas kerja sesuai dengan standar. Hak - hak perawat yang terdapat pada Undang - Undang No.13 Tahun 2003 tentang Ketenagakerjaan, Undang - Undang No.36 Tahun 2014 tentang Tenaga Kesehatan serta Undang - Undang No.38 Tahun 2014 tentang Keperawatan merupakan suatu sistem hukum berdasarkan teori Sudikno Mertokusumo.

Dengan belum terlaksananya hak - hak perawat perempuan maka tidak sesuai dengan teori hak menurut Paton. Implementasi hak - hak perawat perempuan yang bekerja di rumah sakit merupakan salah satu bentuk kesejahteraan tenaga keperawatan terutama dalam bidang kesehatan yaitu reproduksi.

Sehubungan dengan implementasi hak - hak tersebut maka PPNI belum melaksanakan secara optimal fungsi PPNI yang ketiga yaitu menampung, memadukan, menyalurkan dan memperjuangkan aspirasi tenaga keperawatan serta mengembangkan keprofesian dan kesejahteraan tenaga keperawatan. Faktor yang mendukung implementasi hak - hak perawat perempuan sebagai pekerja dan profesi perawat yaitu pemahaman perawat sebagai profesi yang berdampak pada pelayanan kesehatan kepada perawat dan faktor 
yang menghambat implementasi hak - hak perawat perempuan sebagai pekerja dan profesi perawat yaitu hak larangan pemutusan hubungan kerja terhadap pekerja perempuan hamil, melahirkan, gugur kandungan, atau menyusui bayinya, perlindungan terhadap pekerja perempuan yang bekerja pada malam hari, masa menyusui, cuti haid dan cuti hamil dan melahirkan serta cuti keguguran yaitu berupa faktor normatif (yuridis) dan faktor non normatif (non teknis).

Faktor normatif yaitu peraturan internal rumah sakit yaitu perjanjian kerja dan peraturan perusahaan yang bertentangan dengan undang - undang sehingga berdampak pada belum terwujudnya kepastian hukum, keadilan dan manfaat pada perawat. Faktor non normatif yaitu dari sumber daya manusia yang berupa pemahaman perawat tentang ketengakerjaan yang masih kurang. Dengan adanya faktor yang menghambat implementasi ketentuan hak - hak pada perawat perempuan yang bekerja di rumah sakit maka tidak sesuai dengan teori hak menurut Paton.

\section{KESIMPULAN}

Berdasarkan hasil analisis penelitian tentang "Implementasi Ketentuan Hak-Hak Perawat Perempuan yang Bekerja Di Rumah Sakit Berdasarkan Tinjauan Hak Asasi Manusia" dapat disimpulkan sebagai berikut:

\section{1) Peraturan Internal Rumah Sakit Tentang Hak - Hak Perawat}

Berdasarkan data pada kedua rumah sakit yang diteliti maka dapat disimpulkan:

(a) Peraturan hak sebagai pekerja di kedua rumah sakit terdapat pada perjanjian kerja dan peraturan perusahaan. Perjanjian kerja di kedua rumah sakit tidak memenuhi salah satu syarat sahnya perjanjian yaitu kausa yang halal terkait pemberian upah, sehingga batal demi hukum karena tidak memenuhi syarat objektif perjanjian sesuai ketentuan Pasal 1320 Kitab Undang - Undang Hukum Perdata.

Peraturan perusahaan di kedua rumah sakit berlaku asas lex superior derogat lege inferiori sehingga batal demi hukum. Hal tersebut berkaitan dengan hak cuti hamil dan melahirkan, pemberian upah selama masa cuti, dan perlindungan perawat perempuan yang bekerja pada malam hari.

(b) Hak sebagai profesi di Rumah Sakit Permata Bunda Purwodadi terdapat pada nurse by laws dan di Rumah Sakit Muhammadiyah Semarang diatur pada kewenangan klinis.

2) Implementasi Ketentuan Hak - Hak Perawat Perempuan Di Rumah Sakit Berdasarkan Tinjauan Hak Asasi Manusia

Dalam implementasi ketentuan hak - hak perawat perempuan di rumah sakit didapatkan hasil bahwa belum terlaksananya hak - hak tersebut menurut Undang - Undang No.13 Tahun 2003 tentang Ketenagakerjaan dan Pasal 2 Keputusan Menteri Tenaga Kerja dan Transmigrasi No. KEP 224/MEN/2003 tentang Kewajiban Pengusaha yang Mempekerjakan Pekerja/Buruh Perempuan antara pukul 23.00 sampai dengan 07.00 yaitu hak cuti hamil dan melahirkan yang dibatasi, pemberian upah selama cuti yang bergantung status kepegawaian dan perlindungan terhadap perawat perempuan yang bekerja pada malam hari yang belum optimal. 
Implementasi ketentuan hak - hak perawat perempuan sebagai profesi menurut Undang - Undang No.38 Tahun 2014 tentang Keperawatan dan Undang - Undang No.36 Tahun 2014 tentang Tenaga Kesehatan terdapat hak yang belum terlaksana yaitu terkait memperoleh hak lain yang sesuai dengan ketentuan peraturan perundang - undangan dan fasilitas kerja sesuai dengan standar. Undang - undang No.13 Tahun 2003 tentang Ketenagakerjaan, Undang - Undang No.38 Tahun 2014 tentang Keperawatan dan Undang - Undang No.36 Tahun 2014 tentang Tenaga Kesehatan tersebut saling berkaitan satu sama lain karena merupakan sistem hukum.

3) Faktor - Faktor yang Mempengaruhi Implementasi Hak-Hak Perawat Perempuan Yang Bekerja Di Rumah Sakit Berdasarkan Tinjauan Hak Asasi Manusia

Faktor yang mendukung implementasi hak - hak perawat perempuan sebagai pekerja dan profesi perawat yaitu pemahaman perawat sebagai profesi yang berdampak pada pelayanan kesehatan kepada perawat. Faktor penghambat yaitu peraturan internal rumah sakit yaitu perjanjian kerja dan peraturan perusahaan yang bertentangan dengan undang - undang sehingga berdampak pada belum terwujudnya kepastian hukum, keadilan dan manfaat pada perawat serta sumber daya manusia yang berupa pemahaman perawat tentang ketengakerjaan yang masih kurang.

Dengan adanya faktor penghambat tersebut maka belum mewujudkan kepastian hukum keadilan dan manfaat pada perawat.

\section{SARAN}

1) Bagi rumah sakit untuk membuat atau mengubah peraturan internal yaitu peraturan pekerjaan dan perjanjian kerja mengenai hak reproduksi perawat perempuan sesuai dengan Undang - Undang No.13 Tahun 2003 tentang Ketenagakerjaan, Undang Undang No.38 Tahun 2014 tentang Keperawatan dan Undang - Undang No.36 Tahun 2014 tentang Tenaga Kesehatan.

2) Bagi perawat meningkatkan pengetahuan dengan membaca dan memahami mengenai hak - hak perawat sebagai pekerja dan profesi yang bekerja di rumah sakit.

3) Bagi Persatuan Perawat Nasional Indonesia (PPNI) untuk meningkatkan kapasitas dalam hukum tenaga kerja sehingga dapat meningkatkan kesejahteraan hak perawat sebagai profesi.

\section{DAFTAR PUSTAKA}

Djumadi, 2008, Hukum Perburuhan Perjanjian Kerja, Ed.2, Jakarta: PT RajaGrafindo Persada.

Halim, Ridwan A, 1990, Hukum Perburuhan Dalam Tanya Jawab, Cet.2, Jakarta: Ghalia Indonesia.

ILO Convention No. 183 Year 2000 (Konvensi ILO mengenai Perlindungan Maternitas) seperti Penghapusan segala bentuk kerja paksa dan kerja wajib, Penghapusan kerja anak, Penghapusan diskriminasi dalam hal pekerjaan dan jabatan serta Kebebasan berserikat dan pengakuan akan hak atas perundingan bersama.

Keputusan Gubernur Jawa Tengah Nomor 560/94 Tahun 2017 tentang Upah Minimum Pada 35 (Tiga Puluh Lima) Kabupaten/Kota Di Provinsi Jawa Tengah Tahun 2018. 
Keputusan Menteri Tenaga Kerja dan Transmigrasi No. KEP 224/MEN/2003 tentang Kewajiban Pengusaha yang Mempekerjakan Pekerja/Buruh Perempuan antara pukul 23.00 sampai dengan 07.00

Kitab Undang - Undang Hukum Perdata

Kristanti, Ivana Dian:"Perlindungan Hukum Terhadap Perawat Yang Bekerja Pada Malam Hari Di Rumah Sakit Harapan", Kota Magelang, 2014, Universitas Atma Jaya Yogyakarta, Jurnal Ilmu Hukum

Mertokusumo, Sudikno, , 1986, Mengenal Hukum (Suatu Pengantar), Cet.1, Yogyakarta: Liberty Yogyakarta.

Peraturan Pemerintah Republik Indonesia Nomor 78 Tahun 2015 tentang Pengupahan

Undang - Undang Dasar Negara Republik Indonesia Tahun 1945.

Undang - Undang No.13 Tahun 2003 tentang Ketenagakerjaan

Undang - Undang No.36 Tahun 2014 tentang Tenaga Kesehatan

Undang - Undang No.38 Tahun 2014 tentang Keperawatan.

Universal Declaration of Human Rights (selanjutnya disebut Deklarasi Universal Hak Asasi Manusia).

Vida, Ana Atika Helmi, dkk : "Perlindungan Atas Terlanggarnya Hak Secara Potensial Bagi Tenaga Kerja Perempuan Yang Bekerja Di Malam Hari Berdasarkan Undang-Undang No.13 Tahun 2003 Tentang Ketenagakerjaan", 2013,Universitas Jember, Artikel Ilmiah Hasil Penelitian Mahasiswa 2013 